\title{
Accidental introduction of anadromous sea lampreys (Petromyzon marinus Linnaeus, 1758) into a European reservoir
}

\author{
Sergio Silva ${ }^{1,2}$, Rufino Vieira-Lanero ${ }^{2}$, Javier Sánchez-Hernández ${ }^{1,2}$, María J. Servia ${ }^{3}$ \\ and Fernando Cobo ${ }^{1,2}$
}

1 Departamento de Zoología y Antropología Física. Facultad de Biología. Universidad de Santiago de Compostela. Campus Vida s/n, 15782 Santiago de Compostela, España.

${ }^{2}$ Estación de Hidrobioloxía "Encoro do Con", Castroagudín s/n, 36617 Vilagarcía de Arousa, Pontevedra, España.

${ }^{3}$ Departamento de Biología Animal, Biología Vegetal y Ecología. Facultad de Ciencias. Universidad de A Coruña. Campus da Zapateira s/n, 15008 A Coruña, España.

*Corresponding author: sergio.silva@usc.es

Received: 15/05/2013 Accepted: 20/01/2014

\begin{abstract}
Accidental introduction of anadromous sea lampreys (Petromyzon marinus Linnaeus, 1758) into a European reservoir Landlocked populations of sea lamprey (Petromyzon marinus) cause tremendous damage to native fish species: nevertheless, none of these populations have been described in Europe. The first record of an introduction of anadromous $P$. marinus into a reservoir in Europe (Portodemouros, NW Spain) is described. Data suggest that this landlocked population was not successful and did not settle in the area because the haematophagous feeding phase was not viable. This agrees with the difficult transition from an anadromous haematophagous life history to a freshwater haematophagous life history. However, the settlement of stable populations of sea lamprey in lakes or reservoirs with more appropriate host populations cannot be discarded.
\end{abstract}

Key words: Anadromous, freshwater, parasitic feeding, landlocked, invasive species, spawning.

\section{RESUMEN}

\section{Introducción accidental de lamprea marina anádroma (Petromyzon marinus Linnaeus, 1758) en un embalse europeo}

Las poblaciones invasoras de Petromyzon marinus que completan su ciclo vital en agua dulce provocan graves daños en las poblaciones de especies autóctonas. Hasta la actualidad ninguna población de este tipo ha sido descrita en Europa. En el presente artículo se describe la primera introducción conocida de la forma anádroma de P. marinus en un embalse europeo (Portodemouros, NO España). Los resultados del seguimiento realizado sugieren que esta población residente no consiguió completar el ciclo vital y establecerse en esta área debido a que la fase de alimentación hematófaga no fue viable. Esto concuerda con la hipótesis de una difícil transición desde el tipo de vida anádromo al desarrollo de un ciclo de vida completo en agua dulce. Sin embargo, el asentamiento de poblaciones estables de lamprea marina en lagos y embalses con poblaciones de huéspedes más apropiadas no puede ser descartado.

Palabras clave: Anádromo, agua dulce, alimentación parásita, especies invasoras, reproducción.

\section{INTRODUCTION}

Currently, several landlocked populations of sea lamprey (Petromyzon marinus Linnaeus, 1758), which complete their life cycle in freshwater, have been described in North America, but none have been described in Europe (Hardisty, 2006). In the upper Laurentian Great Lakes of North 
America, the landlocked form of $P$. marinus is an invasive species that causes tremendous damage to fish stocks and is very expensive to control (Berra, 2001). In contrast, P. marinus is considered as 'Vulnerable' in Europe, listed on Annex II of the EU Habitats Directive and Annex III of the Bern Convention.

During the sport fishing season (spring and summer) of 2008, several anglers caught brown trout (Salmo trutta Linnaeus, 1758) with wounds caused by postmetamorphic $P$. marinus in the Portodemouros reservoir (Ulla River, NW Spain). Two hypotheses may explain the existence of these postmetamorphic sea lampreys in the reservoir. First, the existence of a population isolated by the construction of the dam (1967) that completes its life cycle in freshwater. Second, the introduction of $P$. marinus into this ecosystem after the construction of the dam. The main objective was to investigate the origin of sea lampreys in the Portodemouros reservoir and to determine whether the population was able to complete its life cycle in freshwater.

\section{MATERIALS AND METHODS}

\section{Study area}

The Portodemouros reservoir is located on the main channel of the Ulla River (132 km total length, $2803 \mathrm{~km}^{2}$ ), which drains into the Atlantic Ocean through the Ría de Arousa (NW Spain), with a mean flow of $79.3 \mathrm{~m}^{3} \mathrm{~s}^{-1}$ (Río-Barja \& Rodríguez-Lestegás, 1992). Portodemouros dam, which is 90 meters high and was built in 1967 , creates a reservoir with an area of $11 \mathrm{~km}^{2}$ and a capacity of $297 \mathrm{hm}^{3}$. This dam, together with two other smaller dams (Brandariz and Salto de Touro) located downstream, are the first impassable barrier for anadromous species in the main channel of the River Ulla (Fig. 1), about $80 \mathrm{~km}$ from the mouth (UTM: 29T 561986E 4742078N).

\section{Field work}

To determine the possible origin of postmetamorphic lampreys caught in the reservoir, tribu-
Table 1. Coordinates (UTM) for sampling points surveyed in the Portodemouros reservoir and its tributaries. Puntos de muestreo prospectados en el embalse de Portodemouros y sus afluentes, con las coordenadas correspondientes (UTM).

\begin{tabular}{ccc}
\hline River & Sampling point & UTM \\
\hline Iso & $\mathrm{I} 1$ & $567815 \mathrm{E} 4749062 \mathrm{~N}$ \\
Boente & $\mathrm{B} 1$ & $572104 \mathrm{E} 4748961 \mathrm{~N}$ \\
Pambre & $\mathrm{P} 1$ & $585408 \mathrm{E} 4745879 \mathrm{~N}$ \\
Ulla & $\mathrm{U} 1$ & $582806 \mathrm{E} 4743988 \mathrm{~N}$ \\
Ulla & $\mathrm{U} 2$ & $581950 \mathrm{E} 4744175 \mathrm{~N}$ \\
Ulla & $\mathrm{U} 3$ & $580918 \mathrm{E} 4744442 \mathrm{~N}$ \\
Ulla & $\mathrm{U} 4$ & $579132 \mathrm{E} 4743545 \mathrm{~N}$ \\
Ulla & $\mathrm{U} 5$ & $576398 \mathrm{E} 4743298 \mathrm{~N}$ \\
Arnego & $\mathrm{A} 1$ & $573321 \mathrm{E} 4739602 \mathrm{~N}$ \\
Arnego & $\mathrm{A} 2$ & $573013 \mathrm{E} 4739062 \mathrm{~N}$ \\
Arnego & $\mathrm{A} 3$ & $572443 \mathrm{E} 4737935 \mathrm{~N}$ \\
Furelos & $\mathrm{F} 1$ & $580051 \mathrm{E} 4746548 \mathrm{~N}$ \\
Furelos & $\mathrm{F} 2$ & $579741 \mathrm{E} 4745876 \mathrm{~N}$ \\
Furelos & $\mathrm{F} 3$ & $580116 \mathrm{E} 4745293 \mathrm{~N}$ \\
\hline
\end{tabular}

taries with a suitable habitat for larval lampreys (Almeida \& Quintella, 2002) were surveyed in July 2008. In total, 14 sampling points spread across 6 tributaries of the reservoir were visited (Table 1, Fig. 1). Surveys were conducted using backpack electrofishing equipment (Hans Grassl $\mathrm{GmbH}$, ELT60II). At each sampling point, the entire suitable habitat for ammocoetes in a 100 meter-long section was prospected with a single pass of electrofishing (Moser et al., 2007). The minimum fishing time at each location was 20 minutes, which would increase depending on the surface of the larval habitat that was present.

In the Iberian Peninsula, the larval stage of $P$. marinus lasts an average of four years (Quintella et al., 2003), and the postmetamorphic stage, between the completion of metamorphosis and spawning, lasts one and a half years for both landlocked and anadromous populations (Bergstedt \& Swink, 1995; Silva et al., 2013a). Therefore, to determine the ability of this landlocked population of $P$. marinus to complete its life cycle and to remain viable over time in freshwater, sampling points were re-surveyed four years later, in the summer of 2012. Additionally, in both 2008 and 2012, a walking survey was conducted in each tributary to detect spawning areas with nests.

The ammocoetes that were caught were anaesthetised using a benzocaine solution $(0.3 \mathrm{ml}$ $1^{-1}$ ) to reduce handling stress. After handling, 


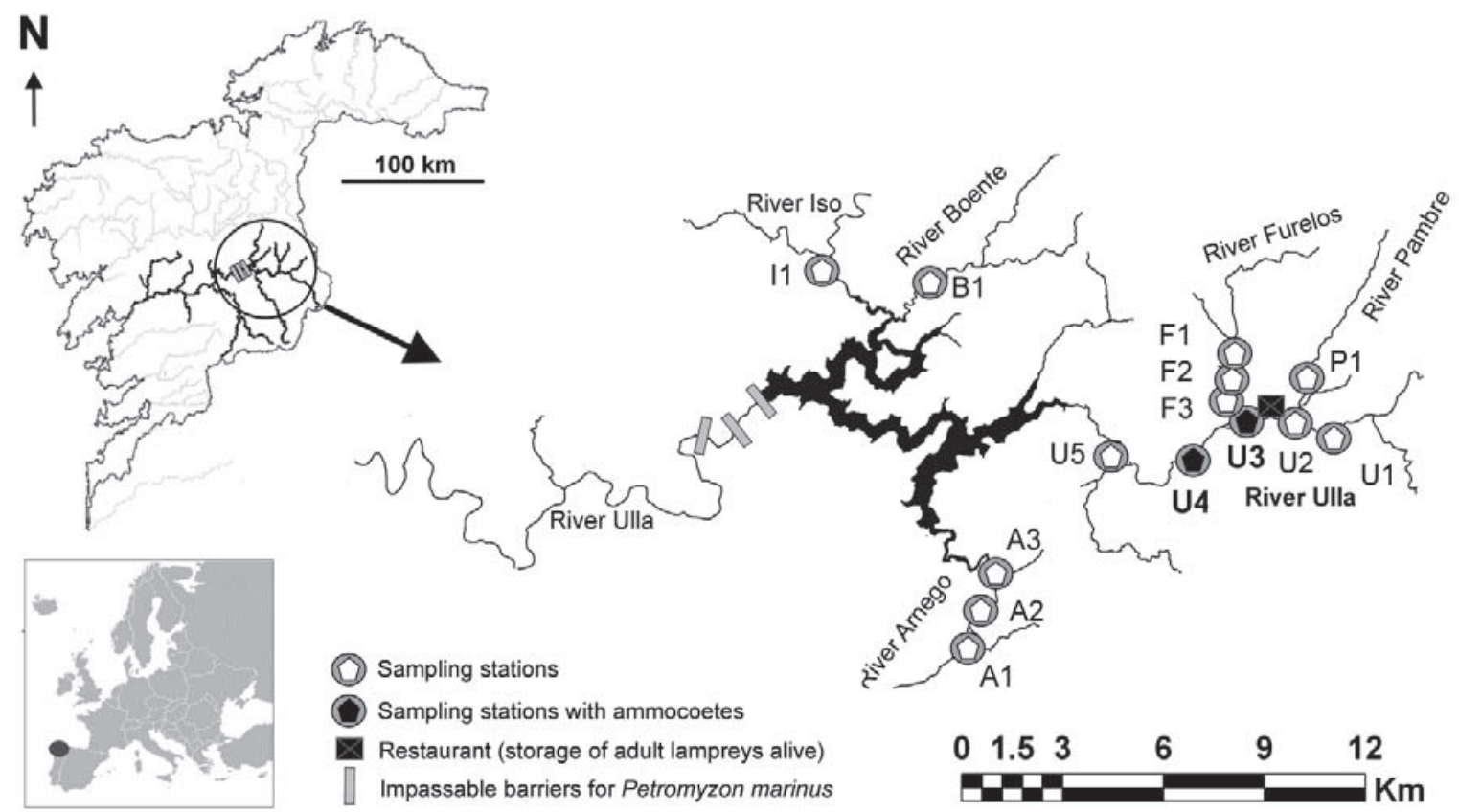

Figure 1. Map of the sampling area in the Portodemouros reservoir and its tributaries. Mapa del área de muestreo en el embalse de Portodemouros y sus afluentes.

individuals were allowed to recover and were then returned to their point of capture. Weight (W) $( \pm 0.1 \mathrm{~g})$ and total length (TL) for P. marinus and furcal length (FL) for $S$. trutta $( \pm 1 \mathrm{~mm})$ were recorded.

\section{RESULTS}

Three individuals of $S$. trutta fished in the Portodemouros reservoir in 2008 were provided by a local angler (Table 2). All of the trout had marks produced by postmetamorphic $P$. marinus, and one (total length: $261 \mathrm{~mm}$ ) was caught with a 211-mm postmetamorphic attached (Table 2, Fig. 2). All of the wounds showed that skin and underlying musculature were perforated at the attachment site, which indicates active feeding by postmetamorphic lampreys (Fig. 2).

During the 2008 electrofishing surveys, ammocoetes were only captured at two of the Ulla River locations (Table 2). U3 showed a density of 0.3 ind $\mathrm{m}^{-2}$ and a biomass of $2.3 \mathrm{~g} \mathrm{~m}^{-2}$, and $\mathrm{U} 4$ showed a density of $0.1 \mathrm{ind}^{-2}$ and a biomass of

Table 2. Total or furcal length (TL, FL) and weight (W) of individuals of Petromyzon marinus and Salmo trutta captured in the Portodemouros reservoir and its tributaries. Longitud total o furcal (TL, FL) y peso $(W)$ de los individuos de P. marinus y S. trutta capturados en el embalse de Portodemouros y sus afluentes.

\begin{tabular}{|c|c|c|c|c|c|c|}
\hline Species & Year & Life stage & Sampling point & Method & TL or FL (mm) & $\mathbf{W}(\mathrm{g})$ \\
\hline P. marinus & 2008 & Ammocoete & U3 & Electrofishing & 175 & 9.2 \\
\hline P. marinus & 2008 & Ammocoete & U3 & Electrofishing & 185 & 9.2 \\
\hline P. marinus & 2008 & Ammocoete & $\mathrm{U} 4$ & Electrofishing & 160 & 8.4 \\
\hline P. marinus & 2008 & Ammocoete & U4 & Electrofishing & 165 & 9.4 \\
\hline P. marinus & 2008 & Postmetamorphic & Reservoir & Sport fishing & 211 & 15.9 \\
\hline S. trutta & 2008 & Adult & Reservoir & Sport fishing & 405 & 650 \\
\hline S. trutta & 2008 & Adult & Reservoir & Sport fishing & 300 & 265 \\
\hline S. trutta & 2008 & Adult & Reservoir & Sport fishing & 261 & 183 \\
\hline
\end{tabular}


$0.8 \mathrm{~g} \mathrm{~m}^{-2}$. Nests were not detected in prospected areas. During the 2012 surveys, neither ammocoetes nor nests were found. Furthermore, we do not know of any new records of fish with wounds caused by $P$. marinus in the Portodemouros reservoir or its tributaries in these four years.

\section{DISCUSSION}

In 2008, ammocoetes were captured in the main channel of the Ulla River upstream of the Portodemouros reservoir, indicating the origin of the postmetamorphic lampreys, which had been caught the same year feeding on $S$. trutta in this reservoir. Although lamprey nests were not found, these ammocoetes were most likely spawned by captive adults at a restaurant 300 meters upstream of the sampling locations (U3 and U4) where the ammocoetes were captured. The live captive adult lampreys, kept for human consumption, were confined in groups in keeper nets within a channel of the Ulla River. Restaurant owners confirmed that these lampreys showed reproductive behaviour during their confinement. Ammocoetes were not captured upstream of the restaurant, suggesting that the population of ammocoetes, and therefore the postmetamorphic individuals captured feeding on $S$. trutta, come from this introduction of spawners and not from a population isolated 40 years ago by the construction of the Portodemouros dam. This is also supported by the lack of evidence of lamprey presence during those 40 years.

The results show the ability of sea lamprey to spawn successfully without an appropriate spawning habitat, considered essential for lamprey egg fertilisation and embryonic development (Hardisty, 2006). However, the abundance and biomass described for this landlocked population are far from the (mean $\pm \mathrm{SE}$ ) abundance $\left(5.0 \pm 1.38\right.$ ind $\mathrm{m}^{-2}$ and biomass $7.2 \pm 2.57 \mathrm{~g} \mathrm{~m}^{-2}$ observed in the stretch of the River Ulla accessible to anadromous species (Cobo et al., 2010).

Our results suggest that this was not a viable population because the haematophagous feeding phase of newly metamorphosed individuals was the most developed stage observed for this population of $P$. marinus. Similar cases, in which the postmetamorphic population was not viable, occurred in an anadromous population of $P$. marinus isolated in two large reservoirs on the Lee River, in Ireland (Kelly \& King, 2001), and a population of anadromous Pacific lamprey Lampetra tridentata (Richardson, 1836) isolated in a large reservoir on the Ash River, in Canada (Beamish \& Northcote, 1989). These results agree with the most accepted hypothesis on the origin of landlocked sea lamprey populations, which states that these organisms may have adapted to complete their life cycle solely in freshwater through genetic and behavioural changes, brought upon by the prolonged exposure (on an evolutionary scale) of anadromous
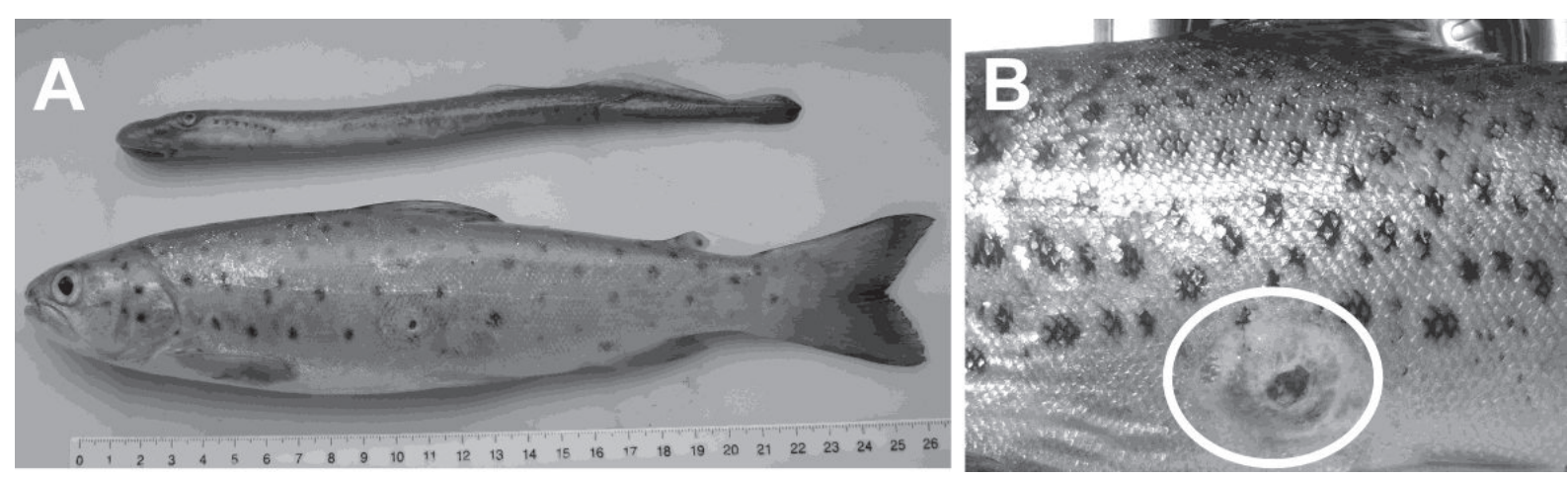

Figure 2. Salmo trutta and postmetamorphic Petromyzon marinus captured feeding on it in the Portodemouros reservoir (A). Perforation wound produced by P. marinus on S. trutta, indicating active feeding by the postmetamorphic lamprey (B). Individuo postmetamórfico de Petromyzon marinus capturado en el embalse de Portodemouros alimentándose de Salmo trutta (A). Herida perforada producida por $\mathrm{P}$. marinus en $\mathrm{S}$. trutta $e$ indicativa de alimentación activa por parte de la lamprea postmetamórfica $(B)$. 
populations to these ecosystems (Beamish \& Northcote, 1989; Waldman et al., 2004; Bryan et al., 2005). These conditions can occur in different European lakes with a connection to the sea, such as several found in Ireland, where postmetamorphic sea lampreys were observed or captured feeding on different fish species (Inland Fisheries Ireland, 2012). In fact, several European lakes have allowed the occurrence of freshwater-resident populations of the anadromous river lamprey Lampetra fluviatilis (Linnaeus, 1758) (Hume et al., 2013).

During the haematophagous stage, the consumption rate of $P$. marinus increases proportionally with increasing size (Farmer, 1980). Similarly, the host size necessary to support this consumption rate also increases; in the ocean, these hosts are supplied by large fishes and cetaceans (Kelly \& King, 2001). However, host size can be limiting in a freshwater environment. This limitation, together with the capacity of European anadromous sea lampreys to actively feed in freshwater, which was demonstrated in this study and recent studies (Silva et al., 2013b; c), suggest that the settlement of stable populations in lakes or reservoirs with more appropriate host stocks cannot be discarded. Therefore, because of the major impact that non-native populations of $P$. marinus can cause on fish communities (Hardisty, 2006), further studies to determine whether anadromous $P$. marinus can complete their life cycle in freshwater should be conducted.

\section{ACKNOWLEDGEMENTS}

The authors thank the staff of the USC Hydrobiology Station "Encoro do Con" for their participation in the surveys. We also thank angler José Casal for his collaboration. This study was partially supported by project 10PXIB2111059PR of Xunta de Galicia and the project MIGRANET of the Interreg IV B SUDOE (South-West Europe) Territorial Cooperation Programme (SOE2/P2/E288). The authors are also grateful for the helpful comments of two anonymous referees.

\section{REFERENCES}

ALMEIDA, P. R. \& B. R. QUINTELLA. 2002. Larval habitat of the sea lamprey (Petromyzon marinus L.) in the River Mondego (Portugal). In: Freshwater fish conservation: options for the future. $\mathrm{M}$. J. Collares-Pereira, M. M. Coelho \& I. G. Cowx (eds): 121-130. Fishing News Books, Blackwell Science, Oxford, UK.

BEAMISH, R. J. \& T. G. NORTHCOTE. 1989. Extinction of a population of anadromous parasitic lamprey, Lampetra tridentata, upstream of an impassible dam. Canadian Journal of Fisheries and Aquatic Sciences, 46: 420-425.

BERGSTEDT, R. A. \& W. D. SWINK. 1995. Seasonal growth and duration of the parasitic life stage of landlocked sea lampreys (Petromyzon marinus). Canadian Journal of Fisheries and Aquatic Sciences, 52: 1257-1264.

BERRA, T. M. 2001. Freshwater Fish Distribution. Academic Press, London, UK.

BRYAN, M. B., D. ZALINSKI, K. B. FILCEK, S. LIBANTS, W. LI \& K. T. SCRIBNER. 2005. Patterns of invasion and colonization of the sea lamprey (Petromyzon marinus) in North America as revealed by microsatellite genotypes. Molecular Ecology, 14: 3757-3773.

COBO, F., S. SILVA, R. VIEIRA-LANERO, M. J. SERVIA, J. SÁNCHEZ-HERNÁNDEZ, S. BARCA, S. RIVAS, M. COUTO, P. GÓMEZ, D. J. NACHÓN, C. MORQUECHO, L. LAGO \& M. C. COBO. 2010. Estado de conservación das poboacións de lamprea mariña en ríos de Galicia. Xunta de Galicia, Consellería do Medio Rural, Dirección Xeral de Conservation da Natureza, Santiago de Compostela, Spain.

FARMER, G. J. 1980. Biology and physiology of feeding in adult lampreys. Canadian Journal of Fisheries and Aquatic Sciences, 37: 1751-1761.

HARDISTY, M. W. 2006. Lampreys: Life without Jaws. Forrest Text, Ceredigion, UK.

HUME, J. B., C. E. ADAMS, C. W. BEAN \& P. S. MAITLAND. 2013. Evidence of a recent decline in river lamprey Lampetra fluviatilis parasitism of a nationally rare whitefish Coregonus lavaretus: is there a diamond in the ruffe Gymnocephalus cernuus?. Journal of fish Biology, 82: 1708-1716.

KELLY, F. L. \& J. J. KING. 2001. A review of the ecology and distribution of three lamprey species, Lampetra fluviatilis (L.), Lampetra planeri (Bloch) 
and Petromyzon marinus (L.): a context for conservation and biodiversity considerations in Ireland. Biology and Environment: Proceedings of the Royal Irish Academy, 101B: 165-185.

INLAND FISHERIES IRELAND. 2012. National Programme: Habitats Directive and Red Data Book Fish species, Executive Report 2011. Ireland. http://www.fisheriesireland.ie/Research/recent-publications.html.

MOSER, M. L., J. M. BUTZERIN \& D. B. DEY. 2007. Capture and collection of lampreys: the state of the science. Reviews in Fish Biology and Fisheries, 17: 45-56.

QUINTELLA, B. R., N. O. ANDRADE \& P. R. ALMEIDA. 2003. Distribution, larval stage duration and growth of the sea lamprey ammocoetes, Petromyzon marinus L., in a highly modified river basin. Ecology of Freshwater Fish, 12: 286-293.

RÍO-BARJA, F. J. \& F. RODRÍGUEZ-LESTEGÁS. 1992. Os Ríos Galegos. Morfoloxía e Réxime. Consello da Cultura Galega, Santiago de Compostela,
Spain.

SILVA, S., M. J. SERVIA, R. VIEIRA-LANERO, S. BARCA \& F. COBO. 2013a. Life cycle of the sea lamprey Petromyzon marinus: duration of and growth in the marine life stage. Aquatic Biology, 18: 59-62.

SILVA, S., M. J. SERVIA, R. VIEIRA-LANERO \& F. COBO. 2013b. Downstream migration and hematophagous feeding of newly metamorphosed sea lampreys (Petromyzon marinus Linnaeus, 1758). Hydrobiologia, 700: 277-286.

SILVA, S., M. J. SERVIA, R. VIEIRA-LANERO, D. J. NACHÓN \& F. COBO. 2013c. Haematophagous feeding of newly metamorphosed European sea lampreys Petromyzon marinus on strictly freshwater species. Journal of Fish Biology, 82: 1739-1745.

WALDMAN, J. R., C. GRUNWALD, N. K. ROY \& I. I. WIRGIN. 2004. Mitochondrial DNA analysis indicates sea lampreys are indigenous to Lake Ontario. Transactions of the American Fisheries Society, 133: 950-960. 